\title{
Distribution of Insect Species as An Indicator for Determining Durian Tree age in Pulo Seunong Plantations, Tangse-Pidie
}

\author{
Rifki Mufti ${ }^{1}$, Muhammad A. Sarong ${ }^{1}$, Khairil Khairil ${ }^{1}$, Safrida Safrida ${ }^{1}$, and Muhammad Sayuthi ${ }^{2}$ \\ ${ }^{1}$ Department of Biology Education, Faculty of Teacher Training and Education, Universitas Syiah Kuala, 23111 Banda Aceh, \\ Indonesia \\ ${ }^{2}$ Department of Plant Pest and Disease Faculty Agriculture, Universitas Syiah Kuala, 23111 Banda Aceh, Indonesia
}

\begin{abstract}
Insects are the dominant animal group on earth with nearly $80 \%$ species of the total animals on the surface. Insects are often found on plantation land such as durian plantations. Durian plants are visited by insects for various purposes such as helping pollination and collecting finding food. This research was focus on the distribution of insect species as an indicator to determine the age of the Durian Tree in the Pulo Senang Plantation, Tangse-Pidie. The purpose of this study was to determine the distribution of indicator insect species based on the age of Durian Tree. This research was conducted in several Durian tree plantations in Pulo Seunong, Pidie from November to October 2017. The method used in this research surveys with random purposive sampling technique. Data were analyzed quantitatively. The results showed that the distribution of insects species found in this study was distributed in 3 parts of durian, namely the root, the stem, and the leaf. The most dominant insect found in the range 0-5 years old, 6-10 years old, and more than 11 years old durian tree were. the species was found on that range age is Solenopsis invicta species (39\%), Dolichoderus thoracicus (33\%), Coponatus sp (29\%).
\end{abstract}

Keywords: distribution of insect, Pulo Seunong, durian plant.

\section{Introduction}

Insects are the dominant animal group on earth with nearly $80 \%$ of the total number of species on earth. Insects in agriculture are widely known as pests and some are predatory parasitoid or natural enemies. The role of visitor insects varies, among others as phytophagous, predators, parasitoids and as plant pollinators[1]. The diversity of visitor insects on plants can be influenced by several factors namely time, flower color, flower shape, number of flowers that bloom and the volume of flower nectar [2]. Leading insects are most commonly found in horticultural plants and fruits. One of them is a durian plant. The presence of insects is also influenced by the color of the flower, the type of flower, and the shape of the flower as a whole which will affect the presence of the insect in a flower. Certain combinations of these characteristics are often associated with certain species of pollinating insects. Pollinator insects (pollinators) are insects that play a role in the process of pollinating plants. Pollination is the event of pollen transfer from anthers to the pistil. Types of insect pollinators include the Order Hymenoptera, Diptera, Lepidoptera, and Coleoptera [3]. The distribution of insects is very diverse, depending on food and other living needs. The distribution of insects in a habitat is also influenced by interactions and predators. The presence of predators can cause uneven distribution.
The results of interviews with writers in the community of Gampong Pulo Seunong community, in addition to rice, coffee, chili, cocoa, durian plants are also one of the leading agricultural commodities in the village. In this durian plant there are several insects so the existence of these insects is beneficial and detrimental to the growth and productivity of durian fruit, with the discovery of these insects it is necessary to identify insect pests, so that appropriate control measures.

The results of the writer's search for insects in durian plantations in Tangse District, Pidie District, show that data collection has never been carried out continuously. Besides, data and information about the spatial distribution patterns of insects in durian plantations in Tangse Subdistrict, Pidie Regency are not yet available and need to be described.

\section{Materials and Methods}

\subsection{Research Place and Time}

This research was conducted at the Gampong Pulo Seunong Community Plantation in Tangse District, Pidie Regency. Data is collected in October to November 2017.

*Corresponding author: mufti.rifki@gmail.com 


\subsection{Research Objects}

The object of this research is the whole species of insects on plants in Plantation Durian Society Pulo Gampong Seunong Tangse Sub Pidie district.

\subsection{Data Collection Techniques}

Data collection was conducted in the Village Community Plantation Pulo Seunong Tangse Sub Pidie district. The location of this research is divided into three stations with observation point determination by purposive sampling. Durian plantations as the region have an area of about 850 $\mathrm{m} 2$ garden, with some community durian planted 115 trees. At the third station has a different plant age.

\section{Results and Discussion}

\subsection{Distribution of indicator species}

In general, insects are categorized as indicator species because they have a function as a decomposer in plants. The material described can be in the form of fallen logs, twigs and other animal waste. In durian, this indicator species functions in plant pollination. If observed from the side of the ecosystem Insects have a function as an object that serves to determine the extinction rate of other species. In addition, the intensity of habitat disturbance also influences the ant species composition difference. the similarity of ant species composition is lower than the similarity of ant species composition in disturbed habitats [4].

Habitat is very important as a place for the survival of insects to breed. To breed, it requires a suitable location and sufficient food availability so that certain insects are only found in that section. In the observation of indicator species that function as decomposers and pollinators on durian, three main species were found, namely Solenopsis invicta species, Dolichoderus thoracicus smith, Coponatus sp. Species - These species spread to certain parts of the durian plant. Based on the age classification of durian trees found differences in insects. These insects have different interests at each durian age. The age classification of plants is classified into 3 groups, namely the age range 0-5 years, 6-10 years, and more than 11 years. This age categorization is based on the distribution of the number of samples of durian plants in the study area so that the number of plant samples is evenly distributed in each age range.

The indicator insect has distribution in 3 locations, namely roots, stems, and leaves. Based on the classification it was found that each species has a certain interest in the durian plant parts and at a certain age. These indicators insects function as pollinating agents and decomposers on durian plants. All three species come from the Formicidae family, the ant family. These ants have different morphologies. The insect family formidae was widespread in disturbed and open habitats [5]. Solenopsis invicta is well known for its painful sting, which in humans causes a burning sensation, usually followed in a day or two by the appearance of a white pustule [6]. The Insect Distribution found at each location is very different. Based on observations of differences in the location of dominance is caused by the location of the foraging insects in the area below or near the surface of the soil which has a lot of rotting litter. Besides these insects choose the location of nesting at the root. The following is a table of the total number of indicator species found.

Table 1.The total number of individuals found in 3 observation stations.

\begin{tabular}{lcc}
\hline \multicolumn{1}{c}{ Name of Species } & $\begin{array}{c}\text { Number of } \\
\text { Individua }\end{array}$ & Percentage \\
\hline $\begin{array}{l}\text { Solenopsis invicta } \\
\text { Dolichoderus }\end{array}$ & 639 & $39 \%$ \\
thoracicus smith & 539 & $33 \%$ \\
Coponatus sp & 477 & $29 \%$ \\
\hline
\end{tabular}

Based on the table, it is known that the Solenopsis invicta species were found as many as 639 individuals at the three stations that were studied with a total of $39 \%$. As for the second and third positions are Dolichoderus thoracicus smith and Coponatus sp species with a percentage of $33 \%$ and $29 \%$.

\subsection{Physical-Chemical Conditions of the Environment in the Pulo Seunong Village Area of Tangse District, Pidie Regency}

The results of the extension of environmental physicalchemical factors throughout the area of Gampong Pulo Seunong District, Tangse District, Pidie Regency have environmental conditions that are suitable for various species of insects on the Durian tree, both insects on durian trees that live on the surface of the ground and freeliving insects (flying). The physical condition of the environment in the research location is presented in the table below:

Table 2. Physical-Chemical Conditions of the Environment in the Pulo Seunong Village, Tangse District, Pidie Regency at Every Time of Sampling

\begin{tabular}{cccc}
\hline Height & $\begin{array}{c}\text { Air } \\
\text { temperature }\end{array}$ & $\begin{array}{c}\text { Light } \\
\text { intensity }\end{array}$ & $\begin{array}{c}\text { Air } \\
\text { Humidity }\end{array}$ \\
\hline$(\mathrm{mdpl})$ & $\left({ }^{\circ} \mathrm{C}\right)$ & $(\mathrm{x} \mathrm{10} \mathrm{Lux})$ & $(\%)$ \\
222 & 29 & 296 & 50 \\
418 & 24 & 280 & 66 \\
\hline
\end{tabular}

The table explains that the environmental conditions in the Pulo Seunong Gampong District of Tangse District of Pidie Regency on the pattern of insect species distribution, measured are physical environmental factors. Environmental conditions at the two observation stations have Air Humidity in physical conditions around 50-66\% with Light Intensity of 296 Lux at $222 \mathrm{MdPL}$ and $280 \mathrm{Lux}$ at $418 \mathrm{MdPL}$ altitudes, having air temperatures ranging from $24-29{ }^{\circ} \mathrm{C}$. that the natural temperature of the soil 
ranges from temperatures below $0^{\circ} \mathrm{C}$ to $33^{\circ} \mathrm{C}$ and changes in temperature can have a major influence on the properties of the soil [7], states that the temperature of a soil is influenced by solar radiation, the position of the sun, geographical location, season, cloud conditions and the process between water and air. Soil temperatures in Indonesia generally range between $26^{\circ} \mathrm{C}-29^{\circ} \mathrm{C}$. Temperatures near the coast are usually a little higher than temperatures in the highlands. Temperature is an important factor in regulating the activity and spread of organisms in nature because it can affect the biochemical reaction processes in the body and regulate metabolic activities. Adaptations and special habits are formed by certain organisms to adapt to changes in environmental temperature [8]. Also, there is the light that affects indirectly, namely as a source of energy for the photosynthesis of plants which are the basis of their lives because they are a source of food. Light is also an important factor in the movement of animal populations.

Table 3. Distribution patterns of insect species that dominate a part of the Durian tree are shown in the table.

\begin{tabular}{|c|c|c|c|c|}
\hline \multicolumn{5}{|c|}{ Species Indikator } \\
\hline $\begin{array}{c}\text { Age } \\
\text { of } \\
\text { Tree }\end{array}$ & $\begin{array}{c}\text { Part of } \\
\text { tree }\end{array}$ & $\begin{array}{l}\text { Name of } \\
\text { Species }\end{array}$ & $\begin{array}{c}\text { Total of } \\
\text { individual } \\
\mathbf{s}\end{array}$ & $\begin{array}{c}\text { Percen } \\
t\end{array}$ \\
\hline \multirow{3}{*}{$\begin{array}{l}<5 \\
\text { years }\end{array}$} & Root & $\begin{array}{c}\text { Solenopsis } \\
\text { invicta }\end{array}$ & 179 & $11 \%$ \\
\hline & Stem & $\begin{array}{l}\text { Dolichoderus } \\
\text { thoracicus } \\
\text { smith }\end{array}$ & 175 & $11 \%$ \\
\hline & Leave & Coponatus sp & 135 & $8 \%$ \\
\hline \multirow{3}{*}{$\begin{array}{l}5-10 \\
\text { years }\end{array}$} & Root & $\begin{array}{c}\text { Solenopsis } \\
\text { invicta }\end{array}$ & 218 & $13 \%$ \\
\hline & Stem & $\begin{array}{c}\text { Dolichoderus } \\
\text { thoracicus } \\
\text { smith }\end{array}$ & 195 & $12 \%$ \\
\hline & Leave & Coponatus sp & 96 & $6 \%$ \\
\hline \multirow{3}{*}{$\begin{array}{l}>10 \\
\text { years }\end{array}$} & Root & Coponatus sp & 246 & $15 \%$ \\
\hline & Stem & $\begin{array}{c}\text { Solenopsis } \\
\text { invicta }\end{array}$ & 242 & $15 \%$ \\
\hline & Leave & $\begin{array}{c}\text { Dolichoderus } \\
\text { thoracicus } \\
\text { smith }\end{array}$ & 169 & $10 \%$ \\
\hline \multicolumn{2}{|c|}{ Total of Species } & & 1655 & $100 \%$ \\
\hline
\end{tabular}

Based on observations in the Table shows that the indicator species dominate the durian tree are the same species between the roots, stems/branches, and leaves. At the root of Solenopsis Invicta is a species that dominates the root section with a total of 179 individuals followed by Dolichoderus thoracicus smith and Coponatus sp with the acquisition of values of 175 and 135 respectively. The stem/branch section also has the same indicator species as the root, where the third number the species gained the most for the Solenopsis Invicta species of 218 individuals, Dolichoderus thoracicus smith 195 and 96 individuals for the Coponatus sp. Leaves obtained different values for the three species of indicator species although the indicator species remained the same, in the branches, leaves, and flowers of Coponatus sp dominate this section with the acquisition of 246 species, followed by Solenopsis invicta with 242 individuals and Dolichoderus thoracicus smith totalling 169 individuals.

\section{Conclusion}

The distribution of insect species in the roots is dominated by Solenopsis invicta species at the age of 1-10 years and ages 11 and older by the species Coponatus sp. The percentage of species dominance at 3 stations ranged from Solenopsis invicta (39\%), Dolichoderus thoracicus smith (33\%), Coponatus sp (29\%). while the measurement of physical factors is $50-66 \%$ humidity with Light Intensity 280-296 Lux, altitude 222-418 MdPL, air temperature ranges from $24-29^{\circ} \mathrm{C}$.

\section{References}

1. Mahmud Z: Serangga Penyerbuk Pada Tanaman Jarak Pagar. Info Tek Jarak Pagar . 2006; 1:19.

2. Faheem M, Aslam M, Razaq M: Pollination ecologi with special reference to insects a review. J. Res. Sci. 2004; 4: 395-409.

3. Falahuddin I, Elfira RP, Esse M: Identifikasi Serangga Coleoptera Pada Tanaman Mentimun (Cucumis sativus L.) Di Desa Tirta Mulya Kecamatan Makarti Jaya KAb. Bayuasin II. Jurnal Biota. 2015; 1 (1).

4. Hasriyanty, Rizali A, Buchori D: Keanekaragaman semut dan pola keberadaannya padadaerah urban di Palu, Sulawesi Tengah (Ant diversity and its occurrence in Palu urban area, Central Sulawesi) Indonesian. Journal of Entomology 2015; 12 : 39-47.

5. Wetterer JK, Davis JR LR : Solenopsis Invicta (Hymenoptera: Formicidae) In The Lesser Antilles. Florida Entomologist. 2010 ; 93(1) : 128-129.

6. Wetterer JK: Exotic spread of Solenopsis invicta Buren Hymenoptera: Formicidae) beyond North America. Sociobiology. 2013; 60 : 50-55.

7. Dahuri: Pengenalan Pelajaran Serangga. Yogyakarta : UGM Press. 1996.

8. Duchlun IA, Arinong R, Nilawati E: Analisis Usaha Tani Rambutan (Nephelium lappecium L.) terhadap Peningkatan Pendapatan Petani. Jurnal Agristem. 2006; 2 (1). 